\title{
Human Capital Reporting (HCR) and Shareholder Value Maximization in Listed Manufacturing Firms in Nigeria
}

\author{
Ademola Adeniran Adewumi ${ }^{1}$, Ilesanmi Isaac Omole ${ }^{1}$, Amos Olatunbosun Talabi $^{1}$ \& Godwin Gabriel Omula ${ }^{1}$ \\ ${ }^{1}$ Department of Accounting, Federal Polytechnic, Ile-Oluji, Ondo State, Nigeria \\ Correspondence: Ademola Adeniran Adewumi, Department of Accounting, Federal Polytechnic, Ile-Oluji, Ondo \\ State, Nigeria.
}

Received: June 5, 2020

Accepted: July 29, 2020

Online Published: April 24, 2021

doi:10.5430/ijfr.v12n4p168

URL: https://doi.org/10.5430/ijfr.v12n4p168

\begin{abstract}
This study examines the impact of human resource reporting (HCR) or disclosures on share price and earnings potential measured by the earnings per share. It adopts an ex-post causal research design and employs secondary data retrieved from annual reports of 30 selected manufacturing firms in Nigeria. Data was analyzed using descriptive statistics, correlation analysis and the quantile regression techniques. The research outcome from the distributional dynamics for share price tends to highlight that the effect of HRD-Index is significant at 5\% for firms at high levels above average financial performance at Q[0.2.] - Q [0.4] and also significant at 5\% for firms at average levels of firm value $\mathrm{Q}[0.5]$ and even below average levels $\mathrm{Q}[0.6]-\mathrm{Q}[0.9]$. Finding thus highlights that the impact of human resource disclosures on share price or market value may not necessarily be a function of the share price levels. The distributional dynamics for EPS used as the measure for earnings potential is similar to that which was observed for Share price and tends to highlight that the effect of human resource disclosure is significant at $5 \%$ for firms at high levels above average earnings per share measure of financial performance at $\mathrm{Q}[0.1], \mathrm{Q}[0.2],. \mathrm{Q}[0.3$.$] and \mathrm{Q}[0.4$.$] and$ also significant at 5\% for firms at average levels of financial performance $\mathrm{Q}[0.5]$ and even below average levels $\mathrm{Q}[0.6]-\mathrm{Q}[0.8]$. The recommendation is that human resource investments should not been looked at as an expense but as a competitive strategy of the firm.
\end{abstract}

Keywords: human capital disclosures, share price, earnings per share, quantile regression

\section{Introduction}

The rising significance of human capital in all sectors of economy led to this new direction in knowledge based economy and thus Knowledge economics is the new reality" (Edvinsson, 2002). In this regards, employees are now largely the most important and invaluable assets in any organization, as it success or otherwise depends on the performances, qualifications and the experiences of members of staff in such organization (Vatasoiu, Cornescu and Motoniu, 2008). "Human Capital" is sometimes used in the literature synonymously with human resource. Regardless of the huge importance of human assets in an enterprise, conventional accounting systems still treat investment/cost associated with the selection, recruitment, training of personnel in an organization as an expense charged against the income statement, and which is used to reduce profit unlike any other physical assets such as Plant and Machinery, Furniture and Fittings, etc., whose cost of acquisition are capitalized in the statement of financial position and only a depreciable amount being charged against the statement of profit or loss account every financial year. The amount of intangible/intermediate assets are also capitalized in the statement of financial position and are amortized for a respective number of years. However, given this era of globalization and an increasing awareness to shift attention from an economy characterized with a physical based assets, to a knowledge based assets such as human capital and intellectual properties as the crucial dynamic to corporate feat. There is therefore an increasing need to determine measure and Report Company's investment in its human capital.

According to Mishra and Mishra (2017) human resource reporting (HCR) can determine the productivity, profitability and sustainability of a firm while also serving as a basis for decision making by the firm's managers as it provides both qualitative and quantitative data on human capital. This process of computing and reporting investments and contributions of employees in a firm to interested parties has come to be known as reporting (Aggarwal and Verma, 2020). Despite the advancements made in the conceptualization and reporting on human resources, there are still several drawbacks. Prominent of these, is the suitable method to be adopted in quantifying 
the expertise, knowledge, competence and contributions of these human assets, since they are not tangible assets of the company. Nevertheless, there is now a growing emphasis and recognition on the importance of intangible assets especially human resource in the value development and maximization chain for companies.

The evolution of knowledge economy from industrial economy also puts greater pressure on companies to use soft resources efficiently as human capital and knowledge, which have become major factors of growth giving credence to the ability of human resource to improve the fortunes of companies' (Nuryaman, 2015). Companies' ability to use information and knowledge has become the key factor of information economics in this modern world (Noradiva, Parastou, and Azlina, 2016) so the companies can effectively transform intangible assets into tangible value. In this knowledge era intellectual capital has become the imperative facet of firm's value. The growing gap between firms' market and book value is generally attributed to the intangible assets rather than tangible assets, because intangible assets are considered as significantly associated with future earnings (Özer, Ergun, and Yilmaz, 2015).

However, the trend of human resource researches in developing economies like Nigeria has lagged behind considerably in terms of volume and coverage. In addition studies on human capital disclossures such as Enyi and Adebawojo, (2014), Enofe, Mgbame, Otuya and Ovie (2013), Micah, Ofurum and Ihendinihu (2012), Akintoye (2012) and Oyewo, Faboyede and Fakile (2014) have not examined its implication on firm shareholder value maximization for manufacturing firms using the quantile regression approach. The rest of the paper is structured as follows. Section 2 gives the literature reviewed, section 3 discusses the methodology, section 4 presents the results of the empirical analysis and section 5 contains the conclusion.

\subsection{Objectives of the Study}

The following are the research objectives:

1. Assess the relationship between Human Capital Reporting (HCR) and Earnings potentials in listed Nigerian manufacturing Companies.

2. Evaluate the impact of Human Capital Reporting (HCR) on the market value in listed manufacturing companies in Nigeria.

\subsection{Research Hypotheses}

For the purpose of this research the following hypotheses were formulated:

H01: HCR has no significant effect on Earnings potentials of listed Nigerian manufacturing companies.

H02: HCR has no significant effect on market value of listed Nigerian manufacturing companies.

\section{Literature Review}

Several studies have been conducted which tried to investigate the extent to human resource reporting affects firm value maximization. For example, Khan and Khan (2010) focused on firms in Bangladesh and examined their human resourcing reporting pattern. The study revealed that the human capital reporting of large firms in Bangladesh are quite high relative to the reporting index used in the study. The authors found out that some of the commonly and regularly reported information regarding human resource includes employee training, recruitment policies, number of employees and training.

Mishra and Mishra (2017) focused on identifying the relationship between profitability amongst other corporate attributes and the level of human capital disclosure in the manufacturing and IT sectors in India. The study made use of a sample of 15 companies listed in the Bombay Stock Exchange (BSE) with data covering the period from 2015 2017. The authors employed a disclosure index as in capturing human capital disclosures. The findings of the study revealed that the level of human capital disclosures did not show any significant link with firm value.

In a most recent study, Aggarwal and Verma (2020) examined the extent of Human Resource (HR) disclosure practices and impact that it has across several measures of firm financial performances. The methodological approach used in the study involves the development of a Human Resource Disclosure Index (HRDI) which consists of 91 items. The sample for the study covered 63 firms quoted on the stock exchange. The findings of the study show that net fixed assets, net sales, market capitalization, earnings per share (EPS), the debt-equity ratio and total number of pages of an annual report significantly affects the extent of HRDI. The authors note that the HR disclosure index created in this study may be utilized by the companies as a benchmark to enhance their HR disclosure in future.

Focusing on EU countries, Pivac, Barac and Tadic (2017) explored the impact of human capital disclosures on firm return on equity and profit ratios. The sample involves companies from 22 European Union countries, with a total of 4,984 company-year observation for a period of five years from 2011 - 2015, which resulted in total firm 
observations of approximately 25,000 , hence being a cross-sectional time series data the study employs panel data analysis. The findings do not support the existence of any significant links between human resource in EU companies and corporate financial performance.

Olajide, Olugbenga, Lateef and Ajayi (2018) examined the impact of human resource disclosures on financial performance of listed firms in Nigeria. Akin to other studies, the authors employed the index approach in measuring human resource disclosures. Data retrieved from financial statements of the selected companies was used for the study and the samples of companies used were 20 . The multiple regression analysis was used for the analysis of the data and the findings of the study revealed that there was a positive relationship between human resource disclosures and firm financial performance.

Syed (2009) conducted a study on HCR in Bangladesh, the study revealed that accounting for labour force is still an embryonic phenomenon in Bangladesh, and that companies that report human asset in their financial statements do so at will as it is not binding on firms to do so. The study found out a pattern for HCR in Bagladeshi listed companies and the relationship between some corporate characteristics (such as firms' size, category of the companies, companies' profitability and the age of the firm) and human resource accounting disclosure. The study concluded that HCR has been found to be significantly related with profitability.

Avazzadehfath and Raiashekar (2011) examined the effect of HCR on decision making in Iranian companies, and their work attempted to explore the extent to which financial investment decisions are influenced by HCR done by companies. The study employed firms quoted in the Iranian Stock Exchange. They concluded that disclosures on human resources is sacrosanct to optimal investment decision

\section{Theoretical Framework: Resource-Based Theory}

Initiated in the mid-1980s by Wernerfelt (1984) and Rumelt (1984), the resource-based view (RBV) theory provides a unique approach to how firms should view their resources in the overall business model. A key emphasis of the resource based view is that firms resources and capabilities are a major source of competitive advantage for firms. Resource-based theories provide explanations on how firms can create value by managing their resources, including human capital, strategically. According to the theory, human capital resources within a firm that are valuable, unique and difficult to imitate will provide firms with competitive advantage (Barney, 1991). For companies that are particularly dependent on employees, financiers and others for survival and growth, there is strong incentive to disclose human capital information as it will not only increase the prospect of attracting and retaining human resources but also to get the necessary contacts, networking, and official sanction via important figures in society. Hence, firms should disclose information on human capital such as experience, qualifications, training, and leadership since these help firms to create value in the capital market. The resource based theory indicated that human resource provides a source of sustained competitive advantage which consists of four basic requirements of value, rare, imitable and organization that must be present within the organization's human resource at all times.

\section{Methodology and Model}

The ex-post research design was used for the study and the study sample covered 30 manufacturing companies that are quoted on the Nigerian Stock Exchange. The time period covered by the study is from 2011-2018. The simple random sampling technique was used for the sample selection and the quantile estimation technique was used for the estimation of the data. The basic framework for the quantile regression model is that the conditional quantiles are linear functions of the explanatory variables. Given that a sample of $\mathrm{N}$ observations from a population that is, $\{(\mathrm{yi}$, $x i): i=1, \ldots, N\}$, in which case the subscript $\mathrm{i}$ indexes each observation, yi is the dependent variable, and $\mathrm{xi}$ is the $\mathrm{K} \times 1$ vector of explanatory variables, which can include the intercept term.

Moreover, let $\tau \in(0,1)$ define the quantile of interest; let $\beta(\tau)$ be the corresponding parameter vector for the vector of characteristics that vary with quantiles; and let $Q \tau$ (.) be the quantile function, which is defined as the inverse function of $F($.), the underlying conditional (on $x i$ ) cumulative distribution function for $y i$. Then the quantile of interest is written as a linear function of a set of characteristics as;

$$
\begin{aligned}
& y i=x_{i}^{\prime} \beta(\tau)+u_{i}(\tau) \\
& Q \tau\left(y_{i} x_{i}\right)=x_{i}^{\prime} \beta(\tau)
\end{aligned}
$$

Where $u_{i}(\tau)$ denotes the error term, which is also a function of the quantile of interest. Based on the preceding two equations, error terms must satisfy the quantile restriction:

$$
Q_{\tau}\left(u_{i}(\tau) \mid x_{i}\right)=0
$$


The parameter estimates for the $\tau^{\text {th }}$ sample quantile minimizes the weighted absolute deviations (the errors); that is,

$$
\operatorname{Min}_{\beta \in \mathbb{R}^{x}}\left[\sum_{i \in\left\{i: y_{i}<x, \beta\right\}} \tau\left|y_{i}-x_{i} \beta\right|+\sum_{i \in\left\{i y_{i} \geq x_{i}, \beta\right\}}(1-\tau)\left|y_{i}-x_{i} \beta\right|\right]
$$

For $\tau=0.5$, one would weigh deviations equally, which is known as median regression. Recall that the $\tau_{\text {th }}$ quantile denotes the maximum value that $\mathrm{y}_{\mathrm{i}}$ can take with given probability $\tau$.

The $\tau^{\text {th }}$ conditional linear quantitle regression of y for given $x=\left(1, x_{1}, x_{2}, \ldots, x_{k}\right)^{T}$ is defined as

$$
\begin{aligned}
Q_{y}(\tau \mid \mathbf{x}) & =Q_{\tau}\left(y \mid x_{1}, x_{2}, \ldots, x_{k}\right)=F^{-1}(\tau \mid \mathbf{x}) \\
& =\mathbf{x}^{T} \beta(\tau)=\beta_{0}(\tau)+\beta_{1}(\tau) x_{1}+\cdots+\beta_{k}(\tau) x_{k}, 0<\tau<1,
\end{aligned}
$$

where $\beta(\tau)=\left(\beta_{0}(\tau), \beta_{1}(\tau), \beta_{2}(\tau), \ldots, \beta_{k}(\tau)\right)^{T}$

Koenker and Bassett (1978) proposed a $L_{1}$-loss function to obtain estimator $\widehat{\beta}(\tau)$ by solving

$$
\widehat{\boldsymbol{\beta}}(\tau)=\arg \min _{\boldsymbol{\beta}(\tau) \in R^{p}} \sum_{i=1}^{n} \rho_{\tau}\left(y_{i}-\mathbf{x}_{i}^{T} \boldsymbol{\beta}(\tau)\right), 0<\tau<1,
$$

where $\rho_{\tau}$ is a loss function

$$
\rho_{\tau}(u)=u(\tau-I(u<0))=\left\{\begin{array}{r}
u(\tau-1), u<0 \\
u \tau, u \geq 0 .
\end{array}\right.
$$

Quantitle regression problem can be formulated as a linear program

$$
\min _{(\boldsymbol{\beta}(\tau), \mathbf{u}, \mathbf{v}) \in R^{p} \times R_{+}^{2 n}}\left\{\tau \mathbf{1}_{n}^{T} \mathbf{u}+(1-\tau) \mathbf{1}_{n}^{T} \mathbf{v} \mid X \beta(\tau)+\mathbf{u}-\mathbf{v}=\mathbf{y}\right\},
$$

Where $1^{T} n$ is an $n$-vector of $1 \mathrm{~s}, \mathrm{X}$ denotes the $\mathrm{n} \times \mathrm{p}$ design matrix, and $\mathrm{u}, \mathrm{v}$ are $\mathrm{n} \times 1$ vectors with elements of $\mathrm{u}_{\mathrm{i}}, \mathrm{v}_{\mathrm{i}}$ respectively (Koenker 2005).

Hence for the study, the quantile model is specified as;

$$
Q_{R}(\tau \mid x)=\widehat{\beta}_{0}(\tau)+\widehat{\beta}_{1}(\tau) x
$$

Where $Q_{\mathrm{R}}(\tau / x)$ be the quantile function for shareholder value maximization measured using return on assets, share price and earnings per share used to measure earning potential and $\beta(\tau)=$ parameter vector for the vector of characteristics that vary with quantiles; $x$ is the $K \times 1$ vector of explanatory variable (human resource disclosure index) and control variable firm size and leverage. 


\section{Presentation of Result}

Table 1. Descriptive statistics

\begin{tabular}{lllllll}
\hline & Mean & Max & Min & Std. Dev. & Jarque-Bera & Prob \\
\hline HRD-Index & 0.5931765 & 1 & 0 & 0.283869 & 1914.201 & 0.000 \\
\hline SP & 34.48802 & 1555.99 & 0.5 & 115.0286 & 183895.3 & 0.000 \\
\hline ROA & 0.239651 & 2.5496 & 0.04 & 0.283278 & 2265.714 & 0.000 \\
\hline EPS & 0.61732 & 2.01 & 0.03 & 0.226255 & 442.958 & 0.000 \\
\hline LEV & 0.586373 & 2.03 & 0 & 0.236074 & 492.81 & 0.000 \\
\hline FSIZE & 7.059722 & 9.22 & 5.09 & 0.781306 & 7.541791 & 0.023 \\
\hline
\end{tabular}

Source: Researcher's compilation (2020) using Eviews 10.0.

Table 1 shows the descriptive statistics for the variables and as observed, the mean for the share price is 34.124 , with a standard deviation of 126.20 which is high and suggests presence of volatility in the share price behaviour of the distribution of companies. The price of the shares ranges from the minimum of 0.5 to a maximum of 1555.99 . The maximum and minimum values stood at 2.549 and 0 respectively. HRD-index has a mean value of 0.593 which indicates a slightly above average human resource disclosure practice of companies in the sample with a standard deviation of 0.2838 . EPS has mean value of 0.617 with a standard deviation of 0.226 . The mean for firm size (FSIZE) as measured using the log of total assets is 7.057 , with a standard deviation of 0.781 . The average value for leverage is 0.586 , with a standard deviation of 0.236 .

Table 2. Pearson correlation

\begin{tabular}{|c|c|c|c|c|c|}
\hline & HRD-Index & SP & LEV & FSIZE & EPS \\
\hline HRD-Index & 1 & & & & \\
\hline $\mathrm{SP}$ & $0.2761 *$ & 1 & & & \\
\hline p-value & 0.000 & & & & \\
\hline LEV & 0.0061 & 0.073505 & 1 & & \\
\hline p-value & 0.8781 & 0.0674 & & & \\
\hline FSIZE & $0.2279 *$ & $0.3331 *$ & $0.1053^{*}$ & 1 & \\
\hline p-value & 0.000 & 0.000 & 0.0087 & & \\
\hline EPS & -0.0288 & $-0.0667 * *$ & 0.017003 & 0.016993 & 1 \\
\hline$p$-value & 0.4746 & 0.0973 & 0.6726 & 0.6728 & \\
\hline
\end{tabular}

Source: Researcher's compilation (2020) using Eviews 10.0

The Pearson correlation result examines the relationship between HRD-Index and financial value performance measures. Particularly, the Pearson correlation statistic was employed in the study. The results show that HRD-Index is positively correlated with SP $(\mathrm{r}=0.2761)$ and significant at $5 \%(\mathrm{p}=0.000)$ and negatively correlated with EPS $(-0.0288)$ though not significant at $5 \%(\mathrm{p}=0.4746)$. In relation to the control variables, HRD-Index is positively correlated with FSIZE $(\mathrm{r}=0.2279)$ and significant at $5 \%(\mathrm{p}=0.000)$ and is positively correlated with LEV $(\mathrm{r}=0.0061)$ though not significant at $5 \%(\mathrm{p}=0.8781)$. The correlation analysis provides insight into the direction and degree of the relationship between the variables. However, it is limited in its inferential capacity as it does necessarily imply functional dependence between the variables. 
Table 3. Quantile regression estimates for HRD-index and share price regression

\begin{tabular}{|c|c|c|c|c|c|}
\hline & Quantile & Coefficient & Std. Error & t-Statistic & Prob. \\
\hline \multicolumn{6}{|l|}{$\mathrm{C}$} \\
\hline & 0.100 & -4.171142 & 3.654235 & -1.141454 & 0.2541 \\
\hline & 0.200 & -12.35340 & 4.703639 & -2.626349 & $0.0088^{*}$ \\
\hline & 0.300 & -22.55272 & 6.441310 & -3.501263 & $0.0005^{*}$ \\
\hline & 0.400 & -37.28340 & 7.727465 & -4.824791 & $0.0000^{*}$ \\
\hline & 0.500 & -55.98262 & 9.933150 & -5.635939 & $0.0000^{*}$ \\
\hline & 0.600 & -89.76468 & 17.17229 & -5.227298 & $0.0000^{*}$ \\
\hline & 0.700 & -120.5384 & 16.96851 & -7.103652 & $0.0000^{*}$ \\
\hline & 0.800 & -156.1496 & 20.75613 & -7.523061 & $0.0000^{*}$ \\
\hline & 0.900 & -287.6430 & 40.70625 & -7.066311 & $0.0000^{*}$ \\
\hline \multirow[t]{5}{*}{ HRD-Index } & 0.100 & 0.790763 & 1.060416 & 0.745711 & 0.4561 \\
\hline & 0.200 & 2.673669 & 1.266307 & 2.111391 & $0.0351^{*}$ \\
\hline & 0.300 & 5.498456 & 1.863877 & 2.950010 & $0.0033^{*}$ \\
\hline & 0.400 & 7.514402 & 2.011697 & 3.735355 & $0.0002 *$ \\
\hline & 0.500 & 12.85260 & 3.892944 & 3.301513 & $0.0010^{*}$ \\
\hline \multirow[t]{9}{*}{ LEV } & 0.600 & 20.44331 & 7.578078 & 2.697690 & $0.0072 *$ \\
\hline & 0.700 & 28.95340 & 9.569926 & 3.025458 & $0.0026^{*}$ \\
\hline & 0.800 & 31.26331 & 14.08529 & 2.219571 & $0.0268 *$ \\
\hline & 0.900 & 36.84152 & 15.71734 & 2.344004 & $0.0194 *$ \\
\hline & 0.100 & 0.005660 & 0.762923 & 0.007418 & 0.9941 \\
\hline & 0.200 & -0.528997 & 0.992280 & -0.533113 & 0.5941 \\
\hline & 0.300 & -0.104167 & 1.059326 & -0.098333 & 0.9217 \\
\hline & 0.400 & -1.486534 & 1.384364 & -1.073803 & 0.2833 \\
\hline & 0.500 & -2.736377 & 1.712342 & -1.598032 & 0.1105 \\
\hline \multirow[t]{13}{*}{ FSIZE } & 0.600 & -1.050323 & 2.362078 & -0.444660 & 0.6567 \\
\hline & 0.700 & -0.295322 & 3.111706 & -0.094907 & 0.9244 \\
\hline & 0.800 & 7.637149 & 15.13753 & 0.504518 & 0.6141 \\
\hline & 0.900 & 34.67851 & 13.63035 & 2.544213 & $0.0112 *$ \\
\hline & 0.100 & 0.633505 & 0.563363 & 1.124505 & 0.2612 \\
\hline & 0.200 & 2.271577 & 0.725108 & 3.132741 & $0.0018^{*}$ \\
\hline & 0.300 & 4.055147 & 0.998349 & 4.061853 & $0.0001 *$ \\
\hline & 0.400 & 6.596904 & 1.205117 & 5.474076 & $0.0000^{*}$ \\
\hline & 0.500 & 9.753827 & 1.568201 & 6.219755 & $0.0000^{*}$ \\
\hline & 0.600 & 15.28499 & 2.866646 & 5.332012 & 0.0000 \\
\hline & 0.700 & 20.78613 & 2.716496 & 7.651818 & 0.0000 \\
\hline & 0.800 & 26.25933 & 3.855296 & 6.811235 & 0.0000 \\
\hline & 0.900 & 45.29554 & 6.731320 & 6.729073 & 0.0000 \\
\hline
\end{tabular}

Source: Researcher's compilation (2020)*sig@ @\%, **sig@10

The usefulness of the quantile regression technique is that unlike the panel regression which does not show the effect of an independent variable on different level of the dependent but is regarded as a mean regression, the quantile regression parameter estimates the change in a specified quantile of the response variable. The conditional quantile 
regression traces the entire distribution of the independent variable, conditional on a set of categories for the dependent variable. As observed, the distributional dynamics for SP tends to highlight that the effect of HRD-Index is significant at $5 \%$ for firms at high levels above average market value at $\mathrm{Q}[0.2],(\mathrm{p}=0.0351), \mathrm{Q}[0.3],(\mathrm{p}=0.0033)$ and $\mathrm{Q}[0.4],(\mathrm{p}=0.00002)$. The effect of HRD-Index is also significant at $5 \%$ for firms at average levels market value in the sample, $\mathrm{Q}[0.5]$ and even below average levels $\mathrm{Q}[0.6],(\mathrm{P}=0.0072), \mathrm{Q}[0.7](\mathrm{p}=0.0026), \mathrm{Q}[0.8](\mathrm{p}=0.0027)$ and $\mathrm{Q}[0.9](\mathrm{p}=0.0194)$. The finding thus highlights that the effect of human resource disclosures on share price may not necessarily be a function of the share price levels. Therefore, whether firms have relative high, average or low share prices, the effect of human resource disclosures on SP is persistent. Consequently, the positive coefficient across all quantile suggest that increases in HRD-Index will result in positive effects on shareholder wealth maximization and this effect is expected to occur irrespective of the current market value of the particular firm. Therefore, the null hypothesis that HRD-Index has no significant effect on shareholder wealth maximization is rejected.

Table 4. Quantile process estimates for HRD-Index and EPS regression

\begin{tabular}{|c|c|c|c|c|c|}
\hline & Quantile & Coefficient & Std. Error & t-Statistic & Prob. \\
\hline \multirow[t]{9}{*}{$\mathrm{C}$} & 0.100 & -0.051178 & 0.100352 & -0.509988 & 0.6102 \\
\hline & 0.200 & 0.135159 & 0.113631 & 1.189456 & 0.2347 \\
\hline & 0.300 & 0.278781 & 0.102786 & 2.712242 & 0.0069 \\
\hline & 0.400 & 0.289074 & 0.090892 & 3.180404 & 0.0015 \\
\hline & 0.500 & 0.322900 & 0.094659 & 3.411196 & $0.0007^{*}$ \\
\hline & 0.600 & 0.369534 & 0.103747 & 3.561857 & $0.0004 *$ \\
\hline & 0.700 & 0.354116 & 0.116690 & 3.034667 & $0.0025^{*}$ \\
\hline & 0.800 & 0.430114 & 0.177472 & 2.423560 & $0.0157^{*}$ \\
\hline & 0.900 & 0.605496 & 0.171684 & 3.526815 & $0.0005^{*}$ \\
\hline \multirow{9}{*}{ HRD-Index } & 0.100 & 0.145709 & 0.048812 & 2.985100 & $0.0029 *$ \\
\hline & 0.200 & 0.213599 & 0.054567 & 3.914465 & $0.0001^{*}$ \\
\hline & 0.300 & 0.271881 & 0.057956 & 4.691145 & $0.0000^{*}$ \\
\hline & 0.400 & 0.290221 & 0.054485 & 5.326669 & $0.0000^{*}$ \\
\hline & 0.500 & 0.274024 & 0.067630 & 4.051825 & $0.0001^{*}$ \\
\hline & 0.600 & 0.299803 & 0.068531 & 4.374691 & $0.0000^{*}$ \\
\hline & 0.700 & 0.318182 & 0.077098 & 4.126977 & $0.0000^{*}$ \\
\hline & 0.800 & 0.259774 & 0.112252 & 2.314203 & $0.0210^{*}$ \\
\hline & 0.900 & 0.274702 & 0.060203 & 4.562898 & $0.0000^{*}$ \\
\hline \multirow[t]{9}{*}{ LEV } & 0.100 & 0.055136 & 0.047489 & 1.161029 & 0.2461 \\
\hline & 0.200 & 0.021773 & 0.048493 & 0.448979 & 0.6536 \\
\hline & 0.300 & 0.036389 & 0.033500 & 1.086258 & 0.2778 \\
\hline & 0.400 & 0.016591 & 0.036997 & 0.448440 & 0.6540 \\
\hline & 0.500 & 0.047761 & 0.052405 & 0.911365 & 0.3625 \\
\hline & 0.600 & 0.063506 & 0.048064 & 1.321275 & 0.1869 \\
\hline & 0.700 & 0.011096 & 0.044368 & 0.250093 & 0.8026 \\
\hline & 0.800 & -0.015504 & 0.038839 & -0.399185 & 0.6899 \\
\hline & 0.900 & 0.061009 & 0.101721 & 0.599762 & 0.5489 \\
\hline \multirow[t]{5}{*}{ FSIZE } & 0.100 & 0.025789 & 0.012368 & 2.085108 & 0.0375 \\
\hline & 0.200 & 0.003586 & 0.014721 & 0.243594 & 0.8076 \\
\hline & 0.300 & -0.018683 & 0.013866 & -1.347390 & 0.1783 \\
\hline & 0.400 & -0.011258 & 0.014100 & -0.798451 & 0.4249 \\
\hline & 0.500 & -0.008455 & 0.016007 & -0.528224 & 0.5975 \\
\hline
\end{tabular}

Source: Researcher's compilation (2020) using Eviews 10.0. * sig @ 5\%, **sig@ 10\% 
As observed, the distributional dynamics for EPS is similar to that which was observed for Share price and tends to highlight that the effect of human resource disclosure is significant at $5 \%$ for firms at high levels above average earnings per share measure of financial performance at $\mathrm{Q}[0.1](\mathrm{p}=0.0029), \mathrm{Q}[0.2].(\mathrm{p}=0.0001), \mathrm{Q}[0.3].(\mathrm{p}=0.000)$ and $\mathrm{Q}$ [0.4.]. The effect of human resource disclosures is also significant at $5 \%$ for firms at average levels of financial performance $\mathrm{Q}[0.5](\mathrm{p}=0.000)$ and even below average levels $\mathrm{Q}[0.6], \mathrm{Q}[0.7]$ and $\mathrm{Q}[0.8]$. The finding thus implies that the human resource disclosures by companies in the sample have a significant positive relationship with earnings per share. Importantly also, the relationship tends to not necessarily be a function of the EPS levels. Therefore, whether firms have relative high, average or low EPS levels, the effect of HRD-Index on EPS is persistent. Therefore, companies improving the level and quality of their human resource disclosures can expect positive outcomes for their company value and financial performance. Importantly also firms of different categories in terms of where they may be on the firm value strata can benefit from the positive effects of increased human resource disclosures. The key insight thus, is that companies that place importance on their human resource and improve the quality of human resource considerations can expect to have positive gains. It is logical to anticipate that a satisfied and motivated workforce will be more productive and hence improve firm value. Therefore, the null hypothesis that HRD-Index has no significant effect on earnings potential is rejected.

\section{Conclusion}

The study examined the implications of human resource disclosures on shareholder wealth maximization of listed manufacturing firms in Nigeria. The increasing global attention given to human resource and intangible assets in general fueled by the transitioning to knowledge based economy as provide the impetus for a renewed interest in this research area. Particularly for manufacturing companies in developed economies, where it is believed that human resource element appears less strategic when compared to service firms due to the poor competitiveness of the sector. In Nigeria, several reasons can be adduced for this which though does not fall within the purview of this study. The research outcome from the distributional dynamics for share price tends to highlight that the effect of HRD-Index is significant at $5 \%$ for firms at high levels above average financial performance at Q[0.2.] - Q [0.4] and also significant at $5 \%$ for firms at average levels of firm value $\mathrm{Q}[0.5]$ and even below average levels Q[0.6]-Q[0.9].

The finding thus highlights that the effect of human resource disclosures on share price or market value may not necessarily be a function of the share price levels. Therefore, whether firms have relative high, average or low share prices, the effect of human resource disclosures on share price is persistent. The distributional dynamics for EPS used as the measure for earnings potential is similar to that which was observed for Share price and tends to highlight that the effect of human resource disclosure is significant at 5\% for firms at high levels above average earnings per share measure of financial performance at Q[0.1], Q[0.2.], Q[0.3.] and Q[0.4.]. The effect of human resource disclosures is also significant at $5 \%$ for firms at average levels of financial performance Q[0.5] and even below average levels Q[0.6], Q[0.7] and Q[0.8]. Therefore, whether firms have relative high, average or low EPS or SP levels, the effect of HRD-Index on EPS and SP is persistent. The recommendation is that companies should pay more attention to their human resource. Investment in human resource should not been looked at as an expense but an integral part of the competitive strategy of the firm.

A limitation of the current study is the focus on strictly manufacturing firms which may pose some challenges in generalizing the study findings to non-manufacturing firms due to the uniqueness of such firms. Consequently, the study recommends that other researchers extend their coverage to non-manufacturing firms especially financial firms because of the service oriented nature of such firms. In addition, it would be value-adding for other studies to also look into the mediating effect of International Financial Reporting Standards (IFRS) adoption in the relationship between HCR and firm value.

\section{References}

Aggarwal, K., \& Verma, A. (2020). Effect of company characteristics on human resource disclosure index: empirical evidences from Indian corporate. Management and Labour Journal, 45(1), 85-117. https://doi.org/10.1177/0258042X19890246

Akintoye, I. R. (2012). The relevance of human resource accounting to effective financial reporting. International Journal of Business, Management, and Economic Research, 3(4), 566-572.

Avazzadehfath, F., \& Raiashekar, H. (2011). Decision making based on human resource accounting information and its evaluation method. Asian Journal of Finance and Accounting, 3(1), 14. https://doi.org/10.5296/ajfa.v3i1.883

Barney, J. (1991). Firm resources and sustained competitive advantage. Journal of Management, 17, 99-120. https://doi.org/10.1177/014920639101700108 
Edvinsson, L. (2002). Developing intellectual capital at Skandia. Long Range Planning, 30(3), 366-373. https://doi.org/10.1016/S0024-6301(97)90248-X

Enofe, A. O., Mgbame, C., Otuya, S., \& Ovie, C. (2013). Human resources accounting disclosures in Nigeria quoted firms. Research Journal of Finance and Accounting, 4(13), 7-12.

Enyi, P. E., \& Adebawojo, O. A. (2014). Human resources accounting and decision making in post- industrial economy. American International Journal of Contemporary Research, 4(2).

Ferraro, O., \& Veltri, S. (2011). The value relevance of intellectual capital on the firm's market value: An empirical survey on the Italian listed firms. International Journal of Knowledge-Based Development, 2(1), 66-84. https://doi.org/10.1504/IJKBD.2011.040626

Khan, M. H., \& Khan, M. R. (2010). Human capital disclosure practices of top Bangladeshi companies. Journal of Human Resource Costing \& Accounting, 14(4), 329-349. https://doi.org/10.1108/14013381011105984

Micah, L. C., Ofurum, C. O., \& Ihendinihu, J. U. (2012). Firms financial performance and human resource accounting disclosure in Nigeria. International Journal of Business and Management, 7(14), 67-75. https://doi.org/10.5539/ijbm.v7n14p67

Mishra, L., \& Mishra, R. (2017). Human resource disclosure and its association with corporate attributes. Global Journal of Management and Business Research, 17(5), 9-18.

Noradiva, H., Parastou, A., \& Azlina, A. (2016). The effects of managerial ownership on the relationship between intellectual capital performance and firm value. International Journal of Social Science and Humanity, 6(7), 514. https://doi.org/10.7763/IJSSH.2016.V6.702

Nuryaman. (2015). The influence of intellectual capital on the firm's value with the financial performance as 607 intervening variable. Procedia - Social and Behavioral Sciences, 2(211), 292-298. https://doi.org/10.1016/j.sbspro.2015.11.037

Oladele, P. O., Aribaba, F. O., Lateef, A. O., \& Ajayi, O. M. (2018). An empirical study of human resource accounting disclosure on financial performance of selected listed firms in Nigeria. The Journal of Accounting and Management, 8(2), 70-82.

Oyewo, B. M., Faboyede, O. S., \& Fakile, A. S. (2014). Human resource management and accounting as strategies for achieving global competitiveness and vision 2020 in Nigeria. Journal of South African Business Research, 1-48.

Özer, G., Ergun, E., \& Yılmaz, O. (2015). Effects of intellectual capital on qualitative and quantitative performance: Evidence from Turkey. South African Journal of Economic and Management Sciences, 18(2), 143-154. https://doi.org/10.17159/2222-3436/2015/v18n2a1

Pivac, S., Barać, Z. A., \& Tadić, I. (2017). An analysis of human capital investments, profitability ratios and company features in the EU. Croatian Operational Research Review, 8(1), 167-180. https://doi.org/10.17535/crorr.2017.0010

Rumelt, R. P. (1984). Toward a strategic theory of the firm. In R. B. Lamb (Ed.), Competitive strategic management. New York: Prentice Hall Inc.

Syed, A. M. (2009). Human resource accounting disclosure of Bangladeshi companies and its association with corporate characteristics. BRAC University Journal, 1(1), 35-43.

Vatasoiu, I., Cornescu, A., \& Motoniu, D. (2008). Human resources accounting - accounting for the most valuable asset of an enterprise. Valahia University in Romania, 5(1), 925-931.

Vodák, J. (2011). The importance of intangible assets for making the company's value. Human Resources Management \& Ergonomics, 5(2), 104-119.

Wernerfelt, B. (1984). A resource-based view of the firm. Strategic Management Journal, 9(2), 171-180. https://doi.org/10.1002/smj.4250050207

Appendix

\begin{tabular}{l}
\hline Quantile Process Estimates \\
\hline Equation: UNTITLED \\
\hline Specification: SP C HRD-Index LEV FSIZE \\
\hline
\end{tabular}


Estimated equation quantile tau $=0.5$

Number of process quantiles: 10

Display all coefficients

\begin{tabular}{llllll}
\hline & Quantile & Coefficient & Std. Error & t-Statistic & Prob. \\
\hline C & 0.100 & -4.171142 & 3.654235 & -1.141454 & 0.2541 \\
\hline 0.200 & -12.35340 & 4.703639 & -2.626349 & 0.0088 \\
\hline 0.300 & -22.55272 & 6.441310 & -3.501263 & 0.0005 \\
\hline 0.400 & -37.28340 & 7.727465 & -4.824791 & 0.0000 \\
\hline 0.500 & -55.98262 & 9.933150 & -5.635939 & 0.0000 \\
\hline 0.600 & -89.76468 & 17.17229 & -5.227298 & 0.0000 \\
\hline 0.700 & -120.5384 & 16.96851 & -7.103652 & 0.0000 \\
\hline 0.800 & -156.1496 & 20.75613 & -7.523061 & 0.0000 \\
\hline 0.900 & -287.6430 & 40.70625 & -7.066311 & 0.0000 \\
\hline 0.100 & 0.790763 & 1.060416 & 0.745711 & 0.4561 \\
\hline 0.200 & 2.673669 & 1.266307 & 2.111391 & 0.0351 \\
\hline 0.300 & 5.498456 & 1.863877 & 2.950010 & 0.0033 \\
\hline 0.400 & 7.514402 & 2.011697 & 3.735355 & 0.0002 \\
\hline 0.500 & 12.85260 & 3.892944 & 3.301513 & 0.0010 \\
\hline 0.600 & 20.44331 & 7.578078 & 2.697690 & 0.0072 \\
\hline 0.700 & 28.95340 & 9.569926 & 3.025458 & 0.0026 \\
\hline 0.800 & 31.26331 & 14.08529 & 2.219571 & 0.0268 \\
\hline 0.900 & 36.84152 & 15.71734 & 2.344004 & 0.0194 \\
\hline 0.100 & 0.005660 & 0.762923 & 0.007418 & 0.9941 \\
\hline 0.200 & -0.528997 & 0.992280 & -0.533113 & 0.5941 \\
\hline 0.300 & -0.104167 & 1.059326 & -0.098333 & 0.9217 \\
\hline 0.400 & -1.486534 & 1.384364 & -1.073803 & 0.2833 \\
\hline 0.500 & -2.736377 & 1.712342 & -1.598032 & 0.1105 \\
\hline 0.600 & -1.050323 & 2.362078 & -0.444660 & 0.6567 \\
\hline 0.700 & -0.295322 & 3.111706 & -0.094907 & 0.9244 \\
\hline 0.800 & 7.637149 & 15.13753 & 0.504518 & 0.6141 \\
\hline 0.900 & 34.67851 & 13.63035 & 2.544213 & 0.0112 \\
\hline 0.100 & 0.633505 & 0.563363 & 1.124505 & 0.2612 \\
\hline 0.200 & 2.271577 & 0.725108 & 3.132741 & 0.0018 \\
\hline 0.300 & 4.055147 & 0.998349 & 4.061853 & 0.0001 \\
\hline 0.400 & 6.596904 & 1.205117 & 5.474076 & 0.0000 \\
\hline 0.500 & 9.753827 & 1.568201 & 6.219755 & 0.0000 \\
\hline & 0.600 & 15.28499 & 2.866646 & 5.332012 & 0.0000 \\
\hline & 20.78613 & 2.716496 & 7.651818 & 0.0000 \\
\hline & 26.25933 & 3.855296 & 6.811235 & 0.0000 \\
\hline & 45.29554 & 6.731320 & 6.729073 & 0.0000 \\
\hline & & & & \\
\hline & & & & \\
\hline & 0.900 & & \\
\hline & & & \\
\hline & & & \\
\hline & &
\end{tabular}

Quantile Process Estimates

Equation: UNTITLED

Specification: EPS C HRD-Index LEV FSIZE

Estimated equation quantile tau $=0.5$ 


\begin{tabular}{|c|c|c|c|c|c|}
\hline \multicolumn{6}{|c|}{ Number of process quantiles: 10} \\
\hline \multicolumn{6}{|c|}{ Display all coefficients } \\
\hline & Quantile & Coefficient & Std. Error & t-Statistic & Prob. \\
\hline \multirow[t]{9}{*}{$\overline{\mathrm{C}}$} & 0.100 & -0.051178 & 0.100352 & -0.509988 & 0.6102 \\
\hline & 0.200 & 0.135159 & 0.113631 & 1.189456 & 0.2347 \\
\hline & 0.300 & 0.278781 & 0.102786 & 2.712242 & 0.0069 \\
\hline & 0.400 & 0.289074 & 0.090892 & 3.180404 & 0.0015 \\
\hline & 0.500 & 0.322900 & 0.094659 & 3.411196 & 0.0007 \\
\hline & 0.600 & 0.352905 & 0.102660 & 3.437619 & 0.0006 \\
\hline & 0.700 & 0.354116 & 0.116690 & 3.034667 & 0.0025 \\
\hline & 0.800 & 0.430114 & 0.177472 & 2.423560 & 0.0157 \\
\hline & 0.900 & 0.605496 & 0.171684 & 3.526815 & 0.0005 \\
\hline \multirow[t]{9}{*}{ HRD-Index } & 0.100 & 0.145709 & 0.048812 & 2.985100 & 0.0029 \\
\hline & 0.200 & 0.213599 & 0.054567 & 3.914465 & 0.0001 \\
\hline & 0.300 & 0.271881 & 0.057956 & 4.691145 & 0.0000 \\
\hline & 0.400 & 0.290221 & 0.054485 & 5.326669 & 0.0000 \\
\hline & 0.500 & 0.274024 & 0.067630 & 4.051825 & 0.0001 \\
\hline & 0.600 & 0.299803 & 0.069403 & 4.319754 & 0.0000 \\
\hline & 0.700 & 0.318182 & 0.077098 & 4.126977 & 0.0000 \\
\hline & 0.800 & 0.259774 & 0.112252 & 2.314203 & 0.0210 \\
\hline & 0.900 & 0.274702 & 0.060203 & 4.562898 & 0.0000 \\
\hline \multirow[t]{9}{*}{ LEV } & 0.100 & 0.055136 & 0.047489 & 1.161029 & 0.2461 \\
\hline & 0.200 & 0.021773 & 0.048493 & 0.448979 & 0.6536 \\
\hline & 0.300 & 0.036389 & 0.033500 & 1.086258 & 0.2778 \\
\hline & 0.400 & 0.016591 & 0.036997 & 0.448440 & 0.6540 \\
\hline & 0.500 & 0.047761 & 0.052405 & 0.911365 & 0.3625 \\
\hline & 0.600 & 0.063506 & 0.047969 & 1.323895 & 0.1860 \\
\hline & 0.700 & 0.011096 & 0.044368 & 0.250093 & 0.8026 \\
\hline & 0.800 & -0.015504 & 0.038839 & -0.399185 & 0.6899 \\
\hline & 0.900 & 0.061009 & 0.101721 & 0.599762 & 0.5489 \\
\hline \multirow[t]{9}{*}{ FSIZE } & 0.100 & 0.025789 & 0.012368 & 2.085108 & 0.0375 \\
\hline & 0.200 & 0.003586 & 0.014721 & 0.243594 & 0.8076 \\
\hline & 0.300 & -0.018683 & 0.013866 & -1.347390 & 0.1783 \\
\hline & 0.400 & -0.011258 & 0.014100 & -0.798451 & 0.4249 \\
\hline & 0.500 & -0.008455 & 0.016007 & -0.528224 & 0.5975 \\
\hline & 0.600 & -0.006976 & 0.016645 & -0.419103 & 0.6753 \\
\hline & 0.700 & 0.002941 & 0.017949 & 0.163866 & 0.8699 \\
\hline & 0.800 & 0.008958 & 0.017794 & 0.503427 & 0.6148 \\
\hline & 0.900 & -0.007592 & 0.021618 & -0.351203 & 0.7256 \\
\hline
\end{tabular}

\section{Copyrights}

Copyright for this article is retained by the author(s), with first publication rights granted to the journal.

This is an open-access article distributed under the terms and conditions of the Creative Commons Attribution license (http://creativecommons.org/licenses/by/4.0/). 